\title{
Oxford Dictionary of National Biography
}

\section{Vortigern [Gwrtheyrn]}

\author{
(fl. 5th cent.) \\ David E. Thornton \\ https://doi.org/10.1093/ref:odnb/28354 \\ Published in print: 23 September 2004 \\ Published online: 23 September 2004
}

Vortigern [Gwrtheyrn] ( $f$ l. 5th cent.), ruler in Britain, came to be regarded as responsible for inviting the Anglo-Saxons into Britain. The significance of this role was such that accounts of Vortigern became largely legendary at an early date, and are probably historically unreliable. It seems reasonable to assume that he was some sort of administrative or military overlord of the southern civitates of Britain in the fifth century. That he was wholly or largely responsible for the adventus Saxonum, as later tradition would have it, is perhaps more difficult to accept, though it seems possible that he had some connection with early English mercenaries or settlers. Writing a century after the events he describes, Gildas states in chapter 23 of his De excidio Britanniae that the Britons convened a council (consilium) to determine how best to counter barbarian incursions from the north, and that the councillors and the (superbus tyrannus'proud tyrant') agreed to invite 'Saxon' mercenaries to fight on their behalf and in return gave them the eastern side of Britain. Some manuscripts of the De excidio explicitly name this 'proud tyrant' as Vortigernus or Gurthigernus; and, while it is not clear whether the name was included in the authorial text, the identification with Vortigern is strengthened by the fact that the Old Welsh form Guortigern meant 'high king', suggesting the phrase superbus tyrannus was a typical piece of Gildasian onomastic word play.

It should be stressed that Gildas offers no absolute chronology for these events. While, with the benefit of hindsight, Gildas thought the decision to hire the Saxon mercenaries was an error, in fact it reflects a policy also followed on the continent by other late-Roman leaders, such as Aëtius, and was probably regarded as less erroneous by contemporaries. Archaeology suggests the presence of Germanic mercenaries in fifth-century Britain. Most subsequent accounts of Vortigern are derived ultimately from that of Gildas but add increasing layers of legendary and (no doubt) unhistorical details. The earliest definite named references to him occur in the works of Bede, where Vertigernus or Vurtigernus-synchronized with the emperors Martian and Valentinian III (449-50)-is styled king (rex), and his invitation is linked with the settlement in Kent of Hengist and his son Oeric (or brother Horsa). Subsequently, the Anglo-Saxon Chronicle records for 449 that Hengist and Horsa arrived at Ebbsfleet, Kent, at the invitation of Wyrtgeorn, king of the 
Britons, to fight the Picts; but that in 455 they fought against him at Aylesford, Kent, where Horsa fell. Here, it can be seen how Vortigern had become an essential element in the origin-legend of the kingdom of Kent.

By the early ninth century the Welsh had gathered additional legendary material around the figure of Vortigern, bringing him into conflict with both St Germanus and Ambrosius Aurelianus. The Historia Brittonum, once attributed to Nennius, which also drew upon the English accounts, credits Vortigern with four sons:

Vortimer, who for a time is said to have fought against the English; Cadeyn; Pasgen, said to have ruled the kingdoms of Buellt and Gwrtheyrnion; and lastly, St Faustus (fathered by Vortigern on his own daughter), who founded a monastery at Riez in France. The same source gives three different accounts of his death, including one in which he is burnt to death through the prayers of Germanus, and names his father as Vitalis. Welsh genealogies, of highly dubious value, record Severa, 'daughter of Maximus the king', as his wife. Furthermore, it seems Vortigern acquired the role of ancestor for some early medieval Welsh dynasties. The fragmentary 'pillar of Elise (or Eliseg)', erected in the first half of the ninth century by Cyngen ap Cadell, seems to connect Guarthigirn with the origin of the kingdom of Powys, contrary to the genealogical derivation from Cadell Deyrnllug. That a Welsh dynasty should associate its origins with the figure held responsible for the arrival of the Anglo-Saxons is perhaps surprising, and it is possible that rather there are two different individuals who became identified because of the common personal name Vortigern. Alternatively, it may have been Vortigern's bad reputation which compelled the rulers of Powys to claim a different ancestor. Either way, it seems unlikely that such legendary material can be employed to further illuminate Gildas's account of the 'proud tyrant'. It did, however, make a contribution to the long and circumstantial narrative of Vortigern's life and death which was much later provided by Geoffrey of Monmouth.

\section{Sources}

Gildas: 'The ruin of Britain', and other works, ed. and trans. M. Winterbottom (1978), chap. 23

Bede, Hist. eccl., 1.15; 2.5

Bede, Opera de temporibus, ed. C. W. Jones, Medieval Academy of America, 41 (1943)

$A S C$

T. Mommsen, ed., Chronica minora saec. IV. V. VI. VII., 3, MGH Auctores Antiquissimi, 13 (Berlin, 1898)

Nennius, 'British history' and 'The Welsh annals', ed. and trans. J. Morris (1980)

P. C. Bartrum, ed., Early Welsh genealogical tracts (1966) 
D. N. Dumville, Histories and pseudo-histories of the insular middle ages (1990)

D. P. Kirby, 'Vortigern', BBCS, 23 (1968-70), 37-59

J. N. L. Myres, The English settlements (1986) 